\title{
Tribute to Peter deLeon
}

Edella Schlager

\section{(2) OpenEdition}

\section{Journals}

Electronic version

URL: http://journals.openedition.org/irpp/1223

DOI: 10.4000/irpp.1223

ISSN: 2706-6274

\section{Publisher}

International Public Policy Association

\section{Printed version}

Date of publication: 1 September 2020

Number of pages: 135-137

ISSN: 2679-3873

\section{Electronic reference}

Edella Schlager, "Tribute to Peter deLeon", International Review of Public Policy [Online], 2:2 | 2020,

Online since 01 September 2020, connection on 29 January 2021. URL: http://

journals.openedition.org/irpp/1223 ; DOI: https://doi.org/10.4000/irpp.1223

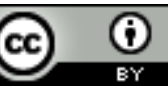

International Review of Public Policy is licensed under a Creative Commons Attribution 4.0 International. 


\section{Tribute to Peter deLeon}

\section{Edella Schlager}

Director, School of Government and Public Policy, University of Arizona

Peter deLeon stood on the shoulders of a giant, Harold Lasswell, one of the truly great political scientists of the $20^{\text {th }}$ century. In turn, Peter was a giant, and supported the work of many graduate students and scholars, not to mention making major conceptual and theoretical contributions to a discipline. Thus, I thought it appropriate to begin this tribute with Harold Lasswell, who argued for a science of policy whereby its practitioners would provide sound knowledge in and of policy making. He grounded this vision in the norms and values of democracy, most especially, as Peter repeatedly noted, in human dignity (deLeon 1994). The policy sciences were to have a problem solving orientation, a sensitivity to context, and the application of multiple types of empirical methods, or more broadly, multiple ways of knowing. As Lasswell (1971:13) explained, "the policy scientist is concerned with mastering the skills appropriate to enlightened decision in the context of public and civic order". The policy sciences of democracy, according to Lasswell, was to be sweeping in scope, encompassing overlapping and interacting decision settings, from intelligence to termination (Lasswell 1971:28). In these decision settings, goal oriented actors pursued multiple values, not only efficiency or power, but also respect, rectitude, and affection (Lasswell 1971).

Peter deLeon, along with Gary Brewer, developed and extended Lasswell's vision in a very popular text, the Foundations of Policy Analysis, making the vision accessible and valuable to generations of policy analysts and scholars. The textbook brought together an in-depth exploration of processes surrounding public policies, staying true to Laswell's vision of problem solving and multiple methods, but also set the standard for textbooks on public policy making. To this day, it is common for textbooks to be organized around the six stages of the policy process: initiation, estimation, selection, implementation, evaluation, and termination (Brewer and deLeon 1983; Sapru 2019). The stages are an intuitive way of organizing and making sense of policy making activities, and they have provided a road map for large swaths of the policy sciences. The individual stages continue to provide the context for rich theorizing, such as agenda setting (Kingdon 1996; Baumgartner and Jones 2009), or implementation (Matland 1995, Cline 2000, O’Toole 2004).

Even so, the Foundations of Policy Analysis was subject to critique from the beginning. Early on, Reuss (1988) warns historians of becoming too enamored with interdisciplinary approaches, such as embracing the policy stages, as presented by Brewer and deLeon (1983), which are ahistorical, and where structure dominates substance (Reuss 1988). He asks, "to what extent can the social sciences, many of which have shown little sensitivity to the dimension of time (sociology is probably the best example), contribute to our understanding of the policy process?"(Reuss 1988:45). But Peter was well ahead of Reuss. In Advice and Consent, he laid out the history and defining events that shaped the development of the policy sciences, especially the policy stages, providing deep insight into knowledge in and of policy making processes. As deLeon and Gallagher (2011) point out, Peter found no reason to revise his assessment of the forces shaping the policy sciences and the policy stages until that article. The rise and prolifera- 
tion of non-profits as key policy process actors and the emergence of governance, deLeon and Gallagher (2011:45) suggest, "have had a significant effect on the structure of the policy cycle." The platform for exploring the ongoing transformation of the policy stages/cycle might have been the highly respected and popular edited volume, Theories of the Policy Process (Sabatier 1999, 2007), however, the policy stages chapter was removed after the first edition to make room for additional policy process theories, with the emphasis on theory (Sabatier 2007). It was a painful decision for both Peter and Paul.

There was virtually no dimension of policy making processes that Peter did not theorize about, or encourage scholars to further investigate and explore. Whether it was policy termination (deLeon 1978; Frantz 1992; Greenwood 2007), or implementation (deLeon and deLeon 2002), his influence can be found across the policy sciences. But one of the most enduring and treasured aspects of Peter's work was his undying commitment to core democratic values and his call to policy sciences scholars to use democracy as their north star. How to best accomplish that? Hew more closely to Lasswell's original vision of a problem solving orientation, which requires multiple disciplines (not only economics), and multiple methods, with positivist approaches taking up less room to allow for a more prominent role for post-positivist methods (deLeon 1994). And, engage with and support a participatory policy analysis. "The crux of participatory policy analysis is that its purpose is to better inform the policy process and, through direct citizen involvement, concomitantly give the citizens a greater voice in and allegiance to the political system and its processes."(deLeon 1994:88).

Great scholars are not only innovative and groundbreaking in their research, but are also powerful mentors. I met a number of Peter's former students at different professional conferences, and their love and respect for him was palpable. While I was not a student of Peter's, he does have a place in my pantheon of mentors, who in critical ways supported me at key junctures in my career. For me, Peter mentored me in his role as editor of Policy Sciences. He published my first single authored article after closely working with me to further develop and sharpen the manuscript's arguments. That experience spoiled me. I assumed all editors were like Peter. And, as the recent editor of the Policy Studies Journal, I worked hard to be the type of editor Peter modeled for me.

In reflecting on Peter's career, I realize how much Elinor Ostrom, my dissertation advisor and friend, and Peter had in common. An openness to diverse approaches, a respect for multiple disciplines, and a knack for making everyone around them better, and better off from the experience.

Baumgartner, F., \& Jones, B. (2009). Agendas and Instability in American Politics (2nd ed.). Chicago, IL: University of Chicago Press.

Brewer, G.\& deLeon, P. (1983). The Foundations of Policy Analysis. Homewood, IL: The Dorcey Press.

Cline, K. (2000). Defining the Implementation Problem: Organizational Management versus Cooperation. Journal of Public Administration Theory and Research, 10(3), 551-571

deLeon, P. (1978). Public Policy Termination: An End and a Beginning. Policy Analysis 4(3):183-184. deLeon, P.(1988). Advice and Consent: the Development of the Policy Sciences. New York: Russell Sage Foundation.

deLeon, Peter. (1994). Reinventing the Policy Sciences: Three Steps Back to the Future. Policy Sci- 
ences, 27, 77-95.

deLeon, P. \& deLeon, L. (2002). Whatever Happened to Policy Implementation? An Alternative Approach. Journal of Public Administration Research and Theory, 12(4), 467-492.

deLeon, P. \& Gallagher, B.K. (2011). A Contemporary Reading of Advice and Consent. Policy Studies Journal, 39(S1), 27-39.

Frantz, J. (1992). Reviving and Revising a Termination Model. Policy Sciences, 25(2), 175- 189.

Greenwood, J. (2007). The Succession of Policy Termination. International Journal of Public Administration, 20(12), 2121-2150.

Kingdon, J. (1995). Agendas, Alternatives, and Public Policies (2nd ed.).New York, NY: Longman.

Lasswell, H. (1971). A Preview of the Policy Sciences. New York, NY: American Elsevier Publishing Co., Inc.

Matland, R. (1995). Synthesizing the Implementation Literature: The Ambiguity-Conflict Model of Policy Implementation. Journal of Public Administration Research and Theory, 5(2), 145-174.

O'Toole, L. (2004). The Theory Practice Issue in Policy Implementation Research. Public Administration, 82(2), 309-329.

Reuss, M. (1988). The Myth and Reality of Policy History: A Response to Robert Kelly. The Public Historian, 10(1), 41-49.

Sabatier, P. (Ed.) (1999). Theories of the Policy Process. Boulder, CO: Westview Press.

Sabatier, P. (Ed.) (2007). Theories of the Policy Process (2nd ed.). Boulder, CO: Westview Press.

Sapru, R. (2019). Public Policy: A Contemporary Perspective. New Delhi: Sage Press. 